\title{
ArcheoSciences
}

Revue d'archéométrie

\section{Preliminary observation on three Late Bronze Age gold items from Ras Shamra-Ugarit (Syria)}

Observations préliminaires de trois objets en or de l'Âge du Bronze récent de Ras Shamra-Ougarit (Syrie)

\section{Romain Prévalet}

\section{OpenEdition}

Journals

Electronic version

URL: https://journals.openedition.org/archeosciences/2111

DOI: 10.4000/archeosciences. 2111

ISBN: 978-2-7535-1598-7

ISSN: 2104-3728

Publisher

Presses universitaires de Rennes

Printed version

Date of publication: 31 December 2009

Number of pages: $129-133$

ISBN: 978-2-7535-1181-1

ISSN: 1960-1360

\section{Electronic reference}

Romain Prévalet, "Preliminary observation on three Late Bronze Age gold items from Ras ShamraUgarit (Syria)", ArcheoSciences [Online], 33 | 2009, Online since 10 December 2012, connection on 31 January 2022. URL: http://journals.openedition.org/archeosciences/2111 ; DOI: https://doi.org/ 10.4000/archeosciences. 2111 


\title{
Preliminary observation on three Late Bronze Age gold items from Ras Shamra-Ugarit (Syria)
}

\author{
Observations préliminaires de trois objets en or de l'Âge du Bronze récent \\ de Ras Shamra-Ougarit (Syrie)
}

\author{
Romain PrÉVALET *
}

\begin{abstract}
Studies of technical mechanisms of ancient gold work from the Near Eastern Bronze Age still remain rare. The identification of marks and reconstruction of manufacturing techniques and processes must involve a multidisciplinary approach, where visual inspection, photomicrographs, experimentation, and elementary analyses are considered. Within the framework of my PhD research on the decoration of ancient gold in the Levant, I conducted a preliminary study of three items, decorated with filigreed and granulated designs, which were discovered at Ras Shamra-Ugarit (Syria) and were dated to the Late Bronze Age. In the present paper, I describe the results of my first observations of the technical characteristics of the filigree and granulation, as well as of the joining processes that were employed by the craftsmen of that famous Levantine kingdom at the end of the second millennium BC. Finally, I also discuss the issues that should be considered in future research.
\end{abstract}

Résumé : Les études sur les techniques du travail de l'or ancien au Proche-Orient à l'àge du Bronze demeurent rares. L'identification des traces et la reconstitution des techniques et des procédés de fabrication impliquent une approche pluridisciplinaire dans laquelle l'observation, les macrophotographies, l'expérimentation et des analyses élémentaires pourraient être considérées. Dans le cadre de ma thèse de doctorat sur la décoration des ors anciens au Levant, j'ai effectué une étude préliminaire de trois objets en or décorés de motifs fligranés et granulés, découverts à Ras Shamra-Ougarit (Syrie) et datés de l'Âge du Bronze récent. L'article propose les résultats d'une première observation des caractéristiques techniques des procédés de filigrane, de granulation et de soudure employés par les artisans de ce prestigieux royaume levantin de la fin du IIe millénaire av. J.-C., ainsi que les problématiques qui devraient être envisagées dans le futur.

Keywords: Filigree, Granulation, Joining, Ugarit, Syria, Bronze Age.

Mots-clés : Filigrane, Granulation, Soudure, Ougarit, Syrie, Âge du Bronze.

\section{INTRODUCTION}

Filigree and granulation are two techniques of decoration (Ogden, 1982) employed on Near Eastern gold jewellery for creating basic geometric patterns on beads, earrings or pendants as early as the $3^{\text {rd }}$ millennium BC (Maxwell-Hyslop, 1971). According to the archaeological data, a technical system that consists of fixing gold wires or granules on a golden core by a metallurgical process appeared in the Levant at the beginning of the $2^{\text {nd }}$ millennium $\mathrm{BC}$ at Byblos, on the Lebanese coast. In western Syria (northern Levant), there is evidence for such techniques from the Middle Bronze Age in the royal tombs of Ebla, and then from the second part of the $2^{\text {nd }}$ millennium BC at Alalakh, Qatna and Ugarit (Nicolini, 1990; Lilyquist, 1993; Prévalet, in press).

*Université Paris I Panthéon-Sorbonne, Institut d'Histoire de l'art et d'Archéologie-3 rue Michelet 75006 Paris. (Romain.Prevalet@malix.univ-paris1.fr) 
The present paper provides a first study of the technical characteristics of filigree and granulation at Ugarit, useful for refining our knowledge of gold jewellery manufacture in the workshops of this Levantine kingdom where diverse influences, cultures and craftsmen interacted at the end of the $2^{\text {nd }}$ millennium BC.

\section{Methodology OF THE STUDY}

This analysis involved three gold items currently in the collections of the National Museum of Damascus in Syria: a pair of crescent-shaped earrings (RS 20.57, S 2584 and RS 20.26, S 2582 - plate 1), a flat round bead (RS 21.197, S 5744 - plate 2) and a composite bead (RS 21.60, S 5726 plate 3). The description of the typology, shape and surface of the wires and granules, as well as the hypothesis related to the identification of the joining processes, are based on direct inspection of the artefacts under a magnifying lens and with micrographs, as the first step of the multidisciplinary methodology of my research.

\section{RESUltS OF OBSERVATIONS}

\section{Wires}

Filigree is applied on the three items not so much to decorate them, but rather to underline the edges or the han-

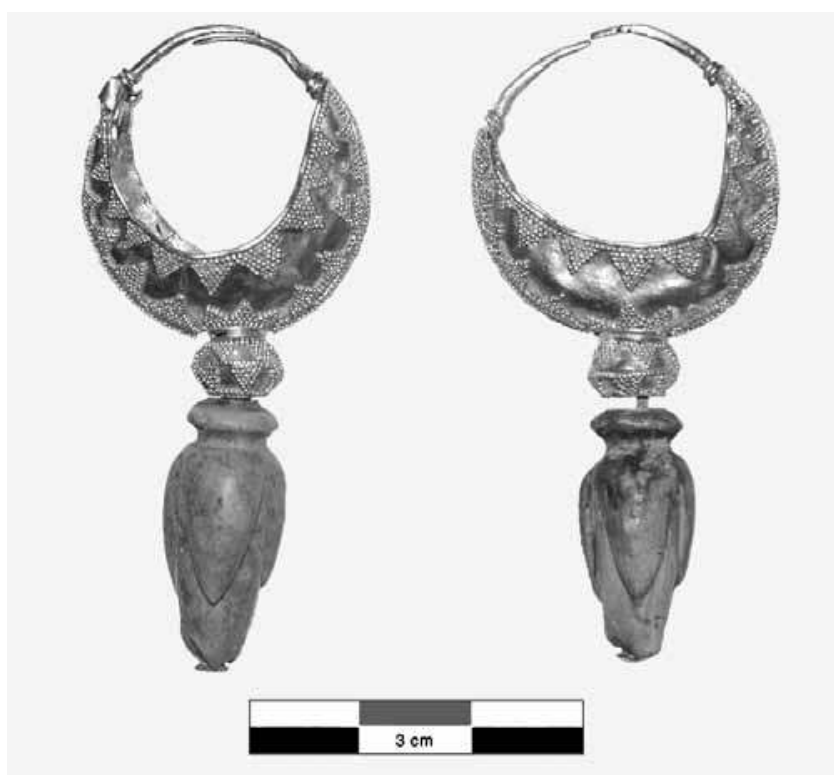

Plate 1: (See colour plate) Pair of crescent-shaped earrings.

Planche 1 : (Voir planche couleur) Paire de boucle d'oreille à navicelle.
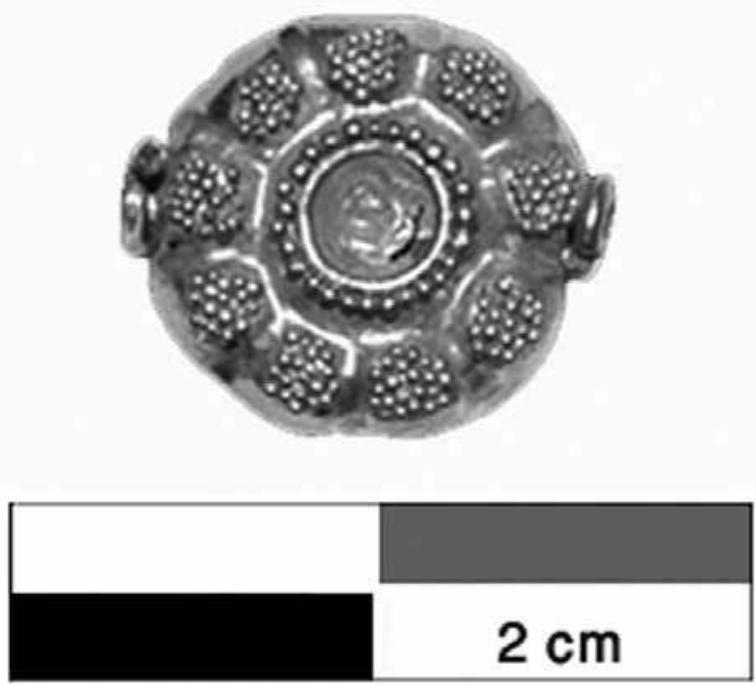

Plate 2: (See colour plate) Flat round bead.

Planche 2: (Voir planche couleur) Perle circulaire plate.
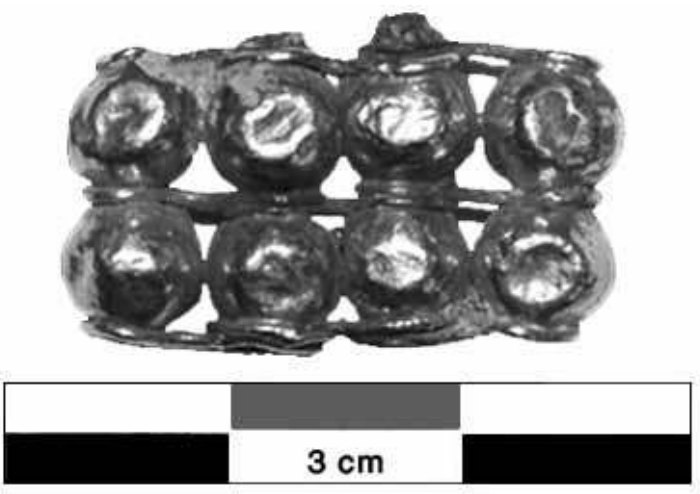

Plate 3: (See colour plate) Composite bead.

Planche 3 : (Voir planche couleur) Perle composite.

ging hole, or to support elements. I have observed only one type of wire, round wire, but it was obtained by different methods. On the flat round bead, the two holes used for suspension are underlined by a plain hexagonal-section wire almost a millimetre in diameter (micrograph 1, 120X). The longitudinal rectangular facets are clearly imprinted on the wire, and the annealing granular surface shows superimposed layers and creases caused by the repeated impact of the hammer. These wires were probably produced from a square rod and hammered so that the surface became more regular and rounder. Its function was to reinforce the thin stamped foil where depressions existed, and also to prevent the edges of the foil from cutting the wire from which the bead is sus- 


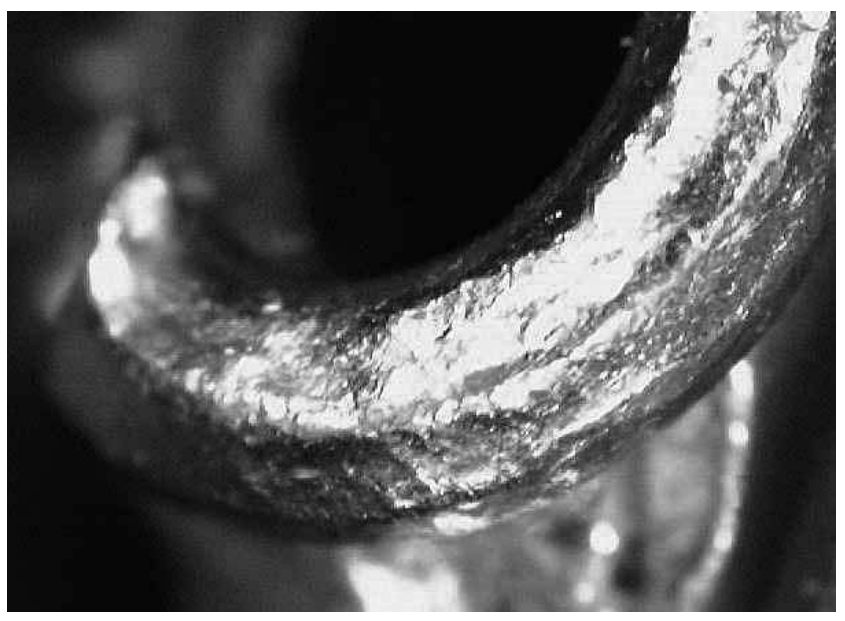

Micrograph 1: Hammered wire. Micrographie 1 : Fil martelé.

pended. This aspect explains its thickness and perhaps also the methods of manufacture.

The technique employed to produce the wires examined on the composite bead and on the pair of earrings must be block-twisting (Mello et al., 1983). The square-section wires of the bead, from 45 up to $75 / 100^{\mathrm{e}}$ in diameter, are coarse with a lot of irregularities in shape and rough marks on their surfaces. Nevertheless, it is possible to observe slight twists of a few extremities that may result from the helical seams created while rolling the twisted wires (Oddy, 1977) (micrograph 2, 30X). In addition, it also seems that some parts of the wires bear hammered marks, such as facets and wide grooves resulting from the crushing of the edges of the square wire.

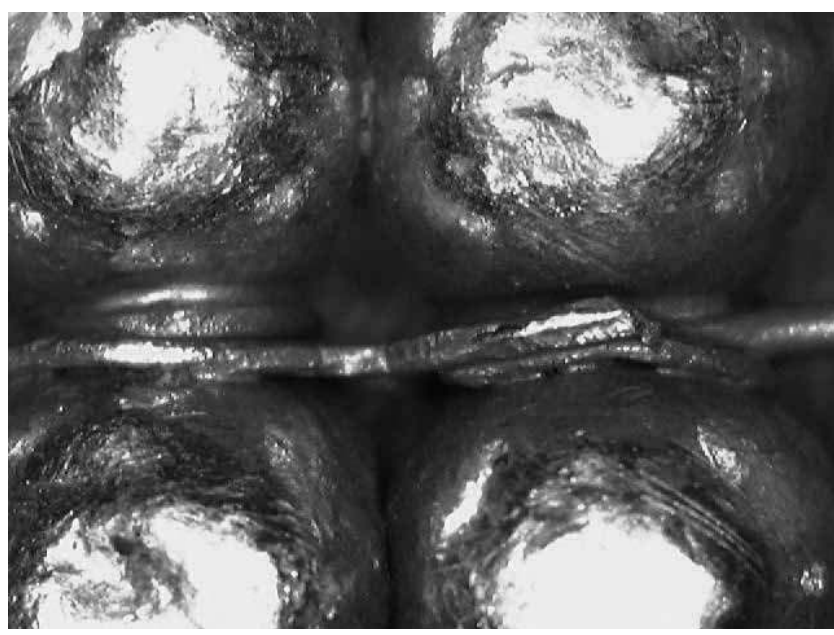

Micrograph 2: Twist of a block-twisted wire. Micrographie 2 : Torsion d'un fil tors roulé.
In contrast, the wires of the earrings are solid and regularly round, with a diameter ranging between 0.50 and 0.60 millimetres. On the border of the crescent shape, a twist of the rectangular-section strip clearly appears where the rolling was unfinished (micrograph 3, 120X), and furrows may be observed on two wires around the barbs of the earrings. Both of these aspects may represent evidence of block-twisting wire.

\section{Granules}

The earrings and the flat round bead are decorated by granulation. The arrangement of the granules in linear, triangular and circular designs is well known from the Bronze Age in the Near East and adjacent areas (Maxwell-Hyslop, 1971; Nicolini, 1990).

At Ugarit, there are medium calibrated granules of $40-60 / 100^{\mathrm{e}}$, often regular; a majority of them is flattened by use. The bead has three large granules of $75 / 100^{\circ}$, and several are irregular in shape and sometimes completely elongated or deformed. In this case, the granules were not well calibrated and graded before their application on the item (cf. micrograph 5).

Different methods for producing granules are known by alchemists, goldsmiths and specialists, and some of them may have been available to the ancient craftsmen (Thouvenin, 1973; Eluère, 1993; Nestler and Formigli, 1994; Carroll, 1974). For example, experimentation shows that bits of strip cut to almost the same dimensions and smelted in charcoal powder in a crucible up to the melting point of gold could produce medium and even coarse

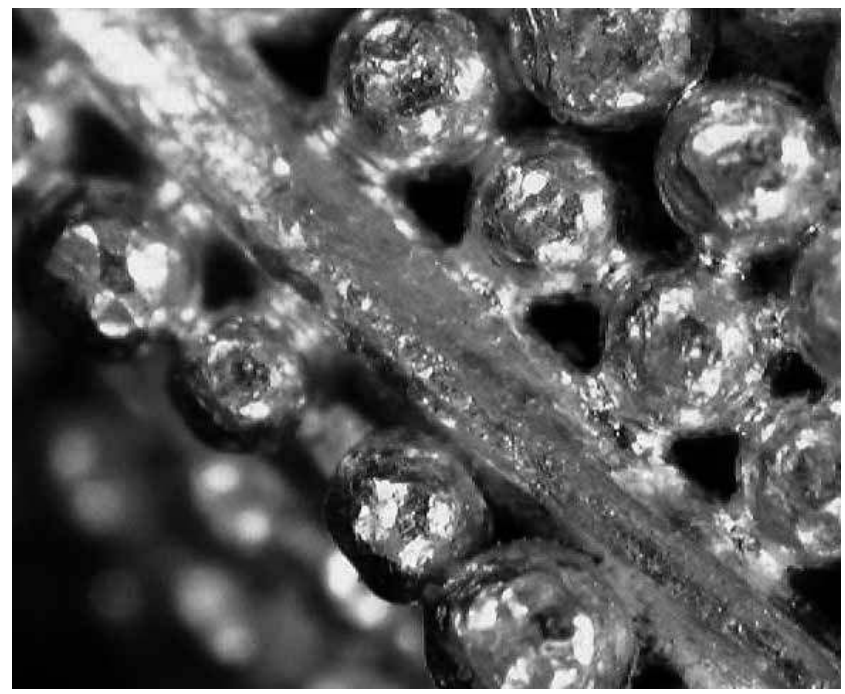

Micrograph 3: Unfinished block-twisted wire.

Micrographie 3 : Fils tors roulé non achevé. 


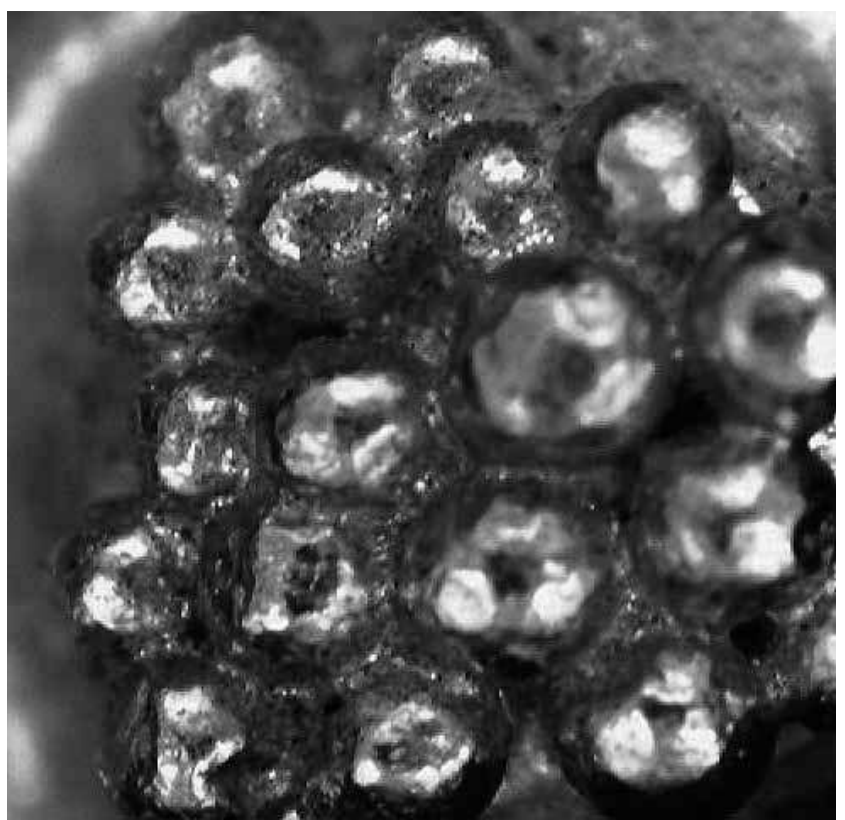

Micrograph 4: Brazing of granules. Micrographie 4: Brasage de granules.

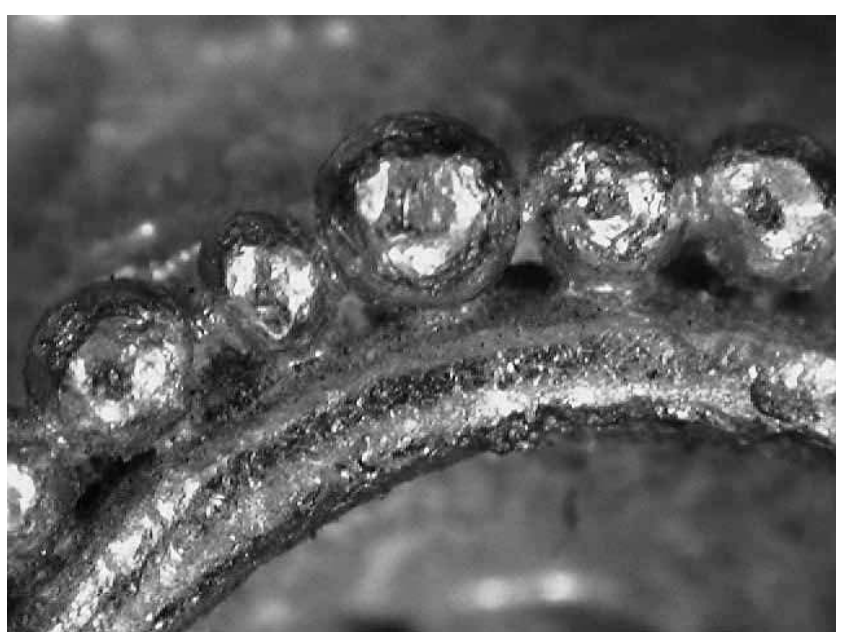

Micrograph 5: Copper salt joining of granules. Micrographie 5: Soudure de granules aux sels de cuivre.

non well-calibrated granules similar to those present on the jewellery of Ugarit.

\section{Joining system}

Microscopic inspection enables us to examine the joining. Two distinct processes were recognized: alloy brazing and copper salt joining, their combination resulting in an alloy which melts at a lower temperature than the melting point of the gold base.

The use of a brazing alloy, which appeared in the Near East during the $4^{\text {th }}$ millennium BC (Nicolini, 1990), can usually be distinguished by the presence of a thick joint, as for example on the composite bead, where the wires are holding the globules by a reddish bulky trail of soldering (cf. micrograph 2). The wires of the flat bead are fixed to the item by two bits of solder, one at the bottom against the base foil and one at the top.

The granule patterns in a circular shape that decorate the bead often look flooded on a thick and compact layer of soldering (micrograph 4). At the centre of the bead there is a round line of granules; each sphere is placed on an independent neck-shaped joint resulting from a copper salt joining (micrograph 5, 120X), a process practiced in the Levant at the beginning of the $2^{\text {nd }}$ millennium $\mathrm{BC}$, at Byblos. The association of alloy brazing and copper salt joining on the same object is also visible on the earrings. Most of their granulated designs are fixed on the gold foil with a copper salt join, as the link between granules of the triangles and the thin neck joint (cf. micrograph 3), in spite of a few thickening-outs or traces of solder at the level of the lines and the triangles, as well as the thick joints of the wires around the barbs, which might represent evidence of alloy brazing. Pieces of solder may have been added where the copper salt joining had not fused because of a lack of contact between the parts.

\section{Conclusion AND Discussion}

Filigree and granulation are not common techniques in Ugarit, as compared to repoussé and incision. Rolled or hammered round wires and medium-calibrated granules characterize those techniques, which are simple processes already known from at least the beginning of the $2^{\text {nd }}$ millennium $\mathrm{BC}$ in the Levant. In terms of the joining operations, the craftsmen employed both alloy brazing and copper salt joining, according to their functions: the first one was probably used more structurally, in the assemblage of the different parts of the object, while the second was more appropriate for minute decoration. However, alloy brazing could also have been practiced to join granules, as in the case of the flat bead. In addition, sometimes it seems that complete control of the joining processes, and more specifically a mastery of the temperature, had not been established, an aspect which led to overheating and flooding.

At this stage of the study, much direct inspection is necessary to sustain the author's assumptions about these three 
gold items representing the filigree and granulation techniques employed for the gold jewellery of Ugarit. In future research work, scientific analysis and examination must be conducted in order to determine the elementary composition of the gold alloy, and to support the identification of the methods of joining the wires and granules. Then, a multidisciplinary study of all gold jewellery in the Levant dating from the Bronze Age should be undertaken in order to investigate a larger collection of filigreed and granulated items, and to determine the technical choices between alloy brazing and copper salt joining.

\section{Acknowledgements}

I thank the Syro-French archaeological excavation team of Ras Shamra-Ugarit and the Directorate General of Antiquities and Museums, Syrian Arab Republic, for their permission to study and publish the gold finds from Ugarit. I should like to extend my gratitude to Alessandro Pacini for his technical advice.

\section{References}

Carroll, D.L., 1974. A Classification for Granulation in Ancient Metalwork. American Journal of Archaeology 78: 33-39.

ELuÈre, C. (ed.), 1993. Outils et ateliers d'orfevres des temps anciens. Antiquités Nationales Mémoire 2. Saint-Germain-en-Laye, Société des amis du Musée des antiquités nationales et du château de Saint-Germain-en-Laye.
LilyQuist, C., 1993. Granulation and Glass: Chronological and Stylistic Investigations at Selected Sites, ca. 2500-1400 B.C.E. BASOR 290: 29-94.

MaXwell-Hyslop, K.R., 1971. Western Asiatic Jewellery ca. 3000612 B.C. London, Methuen and Co. Ltd.

Mello, E., Parrini, P. and Formigli, E., 1983. Etruscan filigree: welding techniques of two gold bracelets from Vetulonia. American Journal of Archaeology, 87, (4): 548-551.

Nestler, G. and Formigli, E., 1994. Granulazione etrusca: un'antica tecnica orafa. Siena: Nuova imagine.

Nicolini, G., 1990. La technique des ors antiques. La bijouterie ibérique du VII au IV siècle. Paris, Picard.

Oddy, A., 1977. The Production of Gold Wire in Antiquity. Gold Bulletin 10(3): 79-87.

Ogden, J., 1982. Jewellery of the Ancient World. Trefoil, London.

Prévalet, R., in press. Techniques de la bijouterie d'or de Ras Shamra-Ougarit: filigrane et granulation, in V. Matoïan, M. Al-Maqdissi, Y. Calvet (eds.), Études ougaritiques II, Ras Shamra - Ougarit XIX. Lyon, Maison de l'Orient et de la Méditerranée.

Thouvenin, A., 1973. La soudure dans la construction des œuvres d'orfèvrerie antique et ancienne. Revue archéologique de l'est et du centre-est 24(1): 11-68.

Whitfield, N., 1990. Round Wire in the Early Middle Ages. Jewellery Studies 4: 13-28.

Wolters, J., 1981. The Ancient Craft of Ancient Granulation: A Re-assessment of Established Concepts. Gold Bulletin 14(3): 119-129. 
